\title{
Association of Leptin Gene G2548A Polymorphism and Leptin Resistance with Insulin Resistance and Obesity among Egyptians
}

\author{
Sara A. Aboelros', Abdel Malik M. Nassar', Mohamed M. El shabrawy', \\ Ranya M. Hassan ${ }^{1 *}$, and Ahmed T. Abdelellah ${ }^{2}$
}

Departments of ${ }^{1}$ Clinical Pathology, and ${ }^{2}$ Cardiology, Faculty of Medicine, Suez Canal University, Egypt

\begin{abstract}
Background leptin (LEP) and leptin receptor (LEPR) genes have been correlated to the pathophysiology of obesity, diabetes, metabolic syndrome and associated complications. LEP G2548A (rs7799039) is a single nucleotide polymorphism (SNP) in leptin gene, the association between G2548A and increased leptinemia is controversial. Aim to study the correlation between LEP G2548A and leptin resistance and their accompaniment with insulin resistance among obese Egyptians. Patients \& Methods: Forty-four obese patients and 44 normal controls were included, and polymerase chain reaction restriction fragment length polymorphism method were used. Serum lipid profile, blood glucose, serum leptin and insulin were also measured. Results Statistically significant positive correlations between insulin resistance and age, diabetes mellitus, hypertension, family history of cardiac disease, hyperlipidemia, family history of obesity, BMI, serum cholesterol, serum triglycerides, serum LDL cholesterol and allele $G$ (for all $p$-value $=0.0001$ except cardiac disease $p$-value $=0.006$ and allele $G$ p-value $=0.001$ ) were found. The percentages of heterozygous AG and homozygous AA genotypes were statistically significantly higher among obese group than among non-obese group $(52.3 \%$ and $25 \%$ vs. 18.2 and $2.3 \%$, respectively) ( $p=0.001)$. In contrast, non-obese group showed statistically significant higher percentage of homozygous genotype GG (Wild type) in comparison to obese group $(79.5 \%$ vs. $25 \%$, respectively) which is statistically significant $(p=0.001)$. Conclusion Current results concluded that leptin gene G2548A polymorphism could be a genetic marker of obesity in Egypt. The correlation between (SNP) in the leptin gene (G2548A) and insulin resistance among obese Egyptians would help in improving knowledge and management of obesity among Egyptian patients.
\end{abstract}

Keywords: SNP, PCR, RFLP, body mass index.

\section{Introduction}

Obesity, one of the most challenging health problems of the last century with a tremendous increase in incidence, is con- sidered an important risk factor for both type 2 diabetes and cardiovascular diseases ${ }^{(1)}$. The prevalence of obesity in Egypt was 43\% in 2011 and it increases with age $^{(2)}$. Obesity has a complex pathogene-

*Corresponding Author: ranyamoustafa@gmail.com 
sis that results from interactions between genetic and environmental factors, which produce malfunctioning of several signaling peptides, which are involved in body energy balance (3). One of the genetic causes of obesity is leptin deficiency and/ or leptin resistance. Leptin is an adipose-derived cytokine present in the circulation in amounts proportional to fat content encoded by the obese (Ob) gene ${ }^{(4)}$. Number of mechanisms has been proposed to explain leptin resistance; these include alterations in the transport of leptin across the blood brain barrier (BBB), perturbations in developmental programming and mutation of the gene for leptin receptors in the brain ${ }^{(5)}$. Leptin expression is increased by increase food intake, insulin, glucocorticoids, endotoxin, and cytokines and is decreased by fasting, testosterone, thyroid hormone, and exposure to cold temperature ${ }^{(6)}$. The leptin (LEP) and leptin receptor (LEPR) genes have been studied in the search for gene variants that are potentially related to the explanation of the mechanism of obesity, diabetes, metabolic syndrome and associated complications ${ }^{(7)}$. LEP G2548A (rs7799039) is an LEP gene single nucleotide polymorphism (SNP) consisting of $G$ to $A$ substitution at nucleotide (nt) -2548 upstream of the ATG start site in the LEP gene promoter. The association between G2548A and increased leptinemia is controversial ${ }^{(8)}$. Leptin increases insulin sensitivity in rats and may improve vascular responses to insulin in states of insulin resistance ${ }^{(9)}$. Leptin secretion by adipocytes is stimulated by insulin, and plasma leptin significantly correlates with plasma insulin. By contrast, under some conditions, leptin negatively regulates insulin signaling ${ }^{(10)}$. Insulin stimulates glucose uptake into tissues, and its ability to do so varies greatly among persons. In insulin resistance, tissues have a diminished ability to respond to the action of insulin. To compensate for resistance, the pancreas produces more insulin. Insulin-resistant persons, therefore, have increase plasma insulin levels ${ }^{(11)}$. This syndrome can be defined as a cluster of abnormalities, including obesity, hypertension, dyslipidemia and type 2 diabetes, that are associated with insulin resistance and compensatory hyper-insulinemia. However, a cause-and-effect relationship between insulin resistance, these diseases and the mechanisms through which insulin resistance influences their development has yet to be conclusively demonstrated ${ }^{(12)}$. This study aimed to investigate the correlation between one of the leptin gene polymorphisms and leptin resistance as a genetic marker of obesity in Egyptian patients, as well as the accompaniment of both insulin resistance and leptin resistance in obese persons.

\section{Patients and Methods}

This study is a case-control study carried out in the clinical pathology department Suez Canal university. Study populations were recruited randomly from the internal medicine outpatient clinic, Suez Canal University hospital, Ismailia. Study Population: the study involved 88 persons divided into two groups: Obese group): 44 subjects with $\mathrm{BMI}$ more than or equal to 25 per $\mathrm{WHO}^{(13)}$, and non-obese control group: 44 subjects with BMI less than 25. Inclusion criteria: Patients whose ages were 20 years and older, of both sexes. Patients with BMI more than 25. Patients who accepted participation on the study. Control group populations were sex and agematched. Exclusion criteria: Pregnant women. People who used any medications for obesity along the course of this study. Patients with known causes of secondary obesity such as hypothyroidism or Cushing syndrome. Data were collected from patients using an interview questionnaire after taking a written consent. Interview Questionnaire: Individuals were interviewed using a questionnaire about the following data: Personal history, history of obesity: onset, course, duration. History of diabetes mellitus, hypertension, dyslipidemia and heart diseases. Family history of obesity and genetic diseases. Physical Examination: Data were recorded for all subjects, including height, weight for the calculation of BMI and general ex- 
amination including general appearance, vital signs, heart, chest and abdomen examinations.

Laboratory Investigations:

Sampling: Six (6.0) $\mathrm{ml}$ of blood collected from each patient as follows: Three (3.0) $\mathrm{ml}$ of blood were collected in EDTA tube for DNA extraction for genotyping. Three (3.0) $\mathrm{ml}$ of blood were collected in sterile plane tube for the following: i) Measurement of serum leptin hormone level and serum insulin level using commerciallyavailable ELISA kits from DRG Systems (DRG International, Inc., USA), ii) Measurement of serum fasting and two-hour post-prandial blood glucose levels and serum total cholesterol, triglycerides, HDLcholesterol and LDL-cholesterol levels by using fully-automated auto-analyzer Cobas C 501 (Roche Diagnostics, Mannheim, Germany). iii) Insulin resistance was determined after using Homeostasis Model Assessment Insulin Resistance (HOMA-IR). HOMA-IR more than 2.5 was considered insulin resistant ${ }^{(14)}$.

\section{PCR technique}

Extraction of genomic DNA: DNA was extracted from patients and control peripheral blood leucocytes using commercially available Spin-column technique kit for DNA extraction (QIAamp ${ }^{\circledR D N A}$ Blood Mini Kit) (Avenue, Stanford, Valencia, CA, US). Genotyping of the Leptin gene G2548A polymorphism: this was carried out using the polymerase chain reaction-restriction fragment length polymorphism (PCRRFLP) assay by using the following primer pairs. Forward primer: $5^{\prime}-$ TCC TCT TTA AAA GCC TAT CCA GTA TTT-3', Reverse primer: 5'- AGC TAG CAA ATA TTT TTG TAA GCA AT- 3'. PCR mixture was as follow: $2 \mu \mathrm{l}$ genomic DNA $(2 \mu \mathrm{g} / \mu \mathrm{l}), 25 \mu \mathrm{l}$ HotStar Taq Master Mix, $19 \mu \mathrm{l}$ RNase free water, $2 \mu \mathrm{l}$ of each primer with final volume of $50 \mu \mathrm{l}$. Amplification will be carried out using Thermal cycler (Mastercycle personal, Ep- pendorf, Germany). The amplification conditions were as follows: initial denaturation at $95^{\circ} \mathrm{C}$ for $15 \mathrm{~min}$, followed by 35 cycles of denaturation at $94^{\circ} \mathrm{C}$ for $1 \mathrm{~min}$, annealing at $55^{\circ} \mathrm{C}$ for $1 \mathrm{~min}$ and extension at $72^{\circ} \mathrm{C}$ for $1 \mathrm{~min}$, followed by final extension at $72^{\circ} \mathrm{C}$ for $10 \mathrm{~min}$. The PCR product was digested using restriction enzyme (Hhal). The digestion was done by adding $10 \mu \mathrm{l}$ of PCR product, $16.3 \mu \mathrm{l}$ of sterile deionized water, $0.2 \mu$ l of $100 \mathrm{X}$ bovine serum albumin and $2 \mu \mathrm{l}$ of $10 \mathrm{X}$ restriction enzyme Buffer, and mixed by pipetting. Finally, $1 \mu \mathrm{l}$ of restriction enzyme (Hhal) was added. The tubes were incubated for 4 hours at $37^{\circ} \mathrm{C}$ followed by heat inactivation for 15 minutes at $65^{\circ} \mathrm{C}$. The $P C R$ products was analyzed by electrophoresis on $2 \%(\mathrm{w} / \mathrm{v})$ agarose gel, the DNA bands was visualized under UV light and photographed using gel documentation system (syngene, UK).

\section{Statistical Analysis}

Data was collected and coded then entered as a spread sheet using Microsoft excel for windows office 2007. Data analysis was done using SPSS 16 program.t-test was used to compare between quantitative data expressed as mean and standard deviation. Pearson's R, Kendall test, Spearman's test and Relative risk were used to assess risk factor. we used Chisquare test to compare between the qualitative data expressed as number and percent. $p$ value is considered as significant when $\mathrm{p}<0.05$.

\section{Results}

The mean age of studied groups showed no statistically significant differences $(p=0.07)$. There were insignificant differences between female and male gender in the studied groups $(p=0.82)$. The mean values of $\mathrm{BMI}$ were higher in the obese group compared to non-obese group 
(32.9 \pm 4.9 vs. $22.2 \pm 1.6 \mathrm{~kg} / \mathrm{m}^{2}, \mathrm{p}=0.0001$ ). Positive family history (first degree relatives) of obesity was statistically significant higher among obese group than among non-obese group ( $86.4 \%$ vs. $43.2 \%$, $\mathrm{p}=0.0001$ ) (Table 1$)$. There were statistically significant positive correlations between insulin resistance and age, diabetes mellitus, hypertension, family history of cardiac disease, hyperlipidemia, family history of obesity, BMI, serum cholesterol, serum triglycerides, serum LDL cholester- ol and allele $G$ (for all $p=0.0001$ except cardiac disease $\mathrm{p}=0.006$ and allele $\mathrm{G}, \mathrm{p}=$ 0.001). There were negative correlations between insulin resistance and both serum HDL cholesterol $(p=0.027)$ and allele A $(p=0.001)$ (Table 2).

Biochemical parameters among study groups: The mean values of serum leptin hormone were statistically significantly higher in obese group in comparison to non-obese group $(63.5 \pm 75.6$ vs. $4.3 \pm 2.1$ $\mathrm{ng} / \mathrm{ml}, \mathrm{p}=0.001$ ) (Table 3 ).

Table 1: Demographic and clinical characteristics of the studied populations

\begin{tabular}{|l|c|c|c|}
\hline \multicolumn{1}{|c|}{ Variables } & Obese $(\mathrm{n}=44)$ & Non-obese $(\mathrm{n}=44)$ & $\mathrm{p}$-value \\
\hline $\begin{array}{l}\text { Age (years) } \\
\text { Mean } \pm \text { SD } \\
\text { Range }\end{array}$ & $\begin{array}{c}42.6 \pm 9.0 \\
22-53\end{array}$ & $\begin{array}{c}34.8 \pm 3.6 \\
30-40\end{array}$ & 0.07 \\
\hline $\begin{array}{l}\text { Gender } \\
\text { Male }\end{array}$ & $18(40.9 \%)$ & $17(38.6 \%)$ & 0.82 \\
Female & $26(59.1 \%)$ & $27(61.4 \%)$ & \\
\hline BMI $\left(\mathrm{kg} / \mathrm{m}^{2}\right)$ & $32.9 \pm 4.9$ & $22.2 \pm 1.6$ & $<0.0001^{* *}$ \\
Mean \pm SD & $27-46$ & $19-24.6$ & \\
Range & $38(86.4 \%)$ & $19(43.2 \%)$ & $<0.0001^{* *}$ \\
\hline Family history of obesity & $6(13.6 \%)$ & $25(56.8 \%)$ & \\
$\quad \begin{array}{l}\text { Positive } \\
\text { Negative }\end{array}$ &
\end{tabular}

*Significant p-value $\leq 0.05, * *$ highly significant p-value $\leq 0.01$.SD standard deviation. BMI

=body mass index

Because leptin reduces food intake that can affect body weight and body mass index, the co-existence of elevated leptin level with obesity is widely interpreted as leptin resistance (normal values for males' $1.00-5.00 \mathrm{ng} / \mathrm{ml}$ and for females 7.00-13.00 $\mathrm{ng} / \mathrm{ml})$. In our study, we found that: in obese group, 39 individuals (88.6\%) had leptin resistance vs. 5 individuals (11.4\%) hadn't leptin resistance. The mean values of fasting blood glucose and fasting insulin were statistically significantly higher in the obese group in comparison to nonobese group $(163 \pm 103 \mathrm{mg} / \mathrm{dl}$ vs. $76 \pm 9$ $\mathrm{mg} / \mathrm{dl}$ in $(\mathrm{p}=0.0001)$ and $14.0 \pm 7.9 \mu \mathrm{U} / \mathrm{ml}$ vs. $9.4 \pm 4.5 \mu \mathrm{U} / \mathrm{ml}(p=0.001)$ respectively. The mean values of serum total cholesterol, serum triglycerides and serum LDL cholesterol were statistically significantly higher in obese group in comparison to nonobese group $(p=0.0001)$. Meanwhile, the mean value of serum HDL-cholesterol was statistically significant lower in the obese group in comparison to non-obese group $(p=0.02)$ (Table 4).

Genotyping of G2548A leptin gene polymorphism among study groups: The PCR product was treated by restriction enzyme (Hhal). The presence of a single band of 294bp represent the presence of $G$ allele (wild type allele), while the presence of two bands of $190 \mathrm{bp}$ and $104 \mathrm{bp}$ represent the presence of allele $A$ (the polymorphic type allele). 
Table 2: Correlations between insulin resistance and other studied variables

\begin{tabular}{|l|c|c|}
\hline \multirow{2}{*}{ Age } & \multicolumn{2}{|c|}{ Insulin resistance } \\
\cline { 2 - 3 } & Correlation coefficient & p-value \\
\hline Gender & 0.539 & $<0.0001^{* *}$ \\
\hline Diabetes mellitus & 0.136 & 0.208 \\
\hline Hypertension (define) & 0.613 & $<0.0001^{* *}$ \\
\hline Cardiac disease (define) & 0.499 & $<0.0001^{* *}$ \\
\hline Hyperlipidemia(mg/dl) & 0.290 & $0.006^{* *}$ \\
\hline Family history of obesity & 0.414 & $<0.0001^{* *}$ \\
\hline BMI (kg/m (m) $^{2}$ & 0.387 & $<0.0001^{* *}$ \\
\hline Leptin resistance & 0.487 & $<0.0001^{* *}$ \\
\hline Cholesterol(mg/dl) & 0.695 & $<0.0001^{* *}$ \\
\hline Triglycerides(mg/dl) & 0.427 & $<0.0001^{* *}$ \\
\hline HDL (mg/dl) & 0.403 & $<0.0001^{* *}$ \\
\hline LDL (mg/dl) & -0.236 & $0.027^{*}$ \\
\hline Allele G & 0.409 & $<0.0001^{* *}$ \\
\hline Allele A & -0.345 & $0.001^{* *}$ \\
\hline
\end{tabular}

Table 3: Comparison of Leptin Hormone Level among Studied Group

\begin{tabular}{|c|c|c|c|c|}
\hline Variables & $\begin{array}{c}\text { Obese } \\
(\mathrm{n}=44)\end{array}$ & $\begin{array}{c}\text { Non-obese } \\
(\mathrm{n}=44)\end{array}$ & OR $(95 \% \mathrm{Cl})$ & P-value \\
\hline Mean leptin level \pm SD & $63.5 \pm 75.6$ & $4.3 \pm 2.1$ & $\mathrm{t}=4.9$ & $<0.0001^{* *}$ \\
\hline
\end{tabular}

*Significant $\mathrm{p}$-value $\leq 0.05, * *$ highly significant $\mathrm{p}$-value $\leq 0.01$, leptin hormone level in blood. OR=odds ratio, $\mathrm{Cl}=$ confidence interval, $\mathrm{t}=$ paired sample $\mathrm{t}$-test

Distribution of different 62548 A genotypes: The obese group showed that $25 \%(n=11)$ were homozygous GG, $52.3 \%(n=23)$ were heterozygous $A G$ and $22.7 \%(n=10)$ were homozygous AA, however non-obese group showed that $79.5 \%(n=35)$ were homozygous GG, $18.2 \%(n=8)$ were heterozygous $A G$ and $2.3 \%(n=1)$ was homozygous AA. The percentages of heterozygous AG and homozygous AA genotypes were significantly higher among obese group than non-obese group (52.3\% and $25 \%$ vs. 18.2 and $2.3 \%$, respectively) $(p=0.001)$. In contrast, non-obese group showed a significant higher percentage of homozygous genotype GG (Wild type) compared to obese group ( $79.5 \%$ vs. $25 \%$, $\mathrm{p}=0.001$ ) (Table 5).

Allele frequencies for $\mathrm{G} 2548 \mathrm{~A}$ gene

In obese group, the frequency of the $G$ and A alleles were $51.9 \%$ and $48.1 \%$ respectively, however, in the nonobese group the frequency of the $\mathrm{G}$ and $\mathrm{A}$ alleles were $98.6 \%$ and $1.4 \%$ respectively. The frequency of allele $G$ was significantly higher in non-obese group in comparison to obese group ( $98.6 \%$ vs. $51.9 \%, p=0.001$ ), while the frequency of allele $A$ was significantly higher in obese group in comparison to non-obese group ( $48.1 \%$ vs. $1.4 \%$ ) $(p=0.001)$ (Table 6). When comparing AG and GG (reference) genotype the odds ratio was 9.15 , which indicates that the carrier of AG genotype has 9 times chance to be obese than GG genotype $(95 \% \mathrm{Cl}=$ 3.2-26.1, $p=0.001)$. When comparing GG and AA genotype the odds ratio was 31.82, which indicates that the carrier of $A A$ genotype has 32 times chance to be obese than GG genotype $(95 \% \mathrm{Cl}=3.6-277.1, \mathrm{p}=$ 0.002) (Table 7). 
Table 4: Biochemical parameters among the studied populations

\begin{tabular}{|l|c|c|c|}
\hline \multirow{2}{*}{ Variables } & Obese $(\mathrm{n}=44)$ & Non-obese $(\mathrm{n}=44)$ & \multirow{2}{*}{-value } \\
\cline { 2 - 3 } & Mean $\pm \mathrm{SD}$ & Mean \pm SD & \\
\hline Fasting insulin $(\mu \mathrm{U} / \mathrm{ml})$ & $14.0 \pm 7.9$ & $9.4 \pm 4.5$ & $0.001^{* *}$ \\
\hline FBG $(\mathrm{mg} / \mathrm{dl})$ & $163 \pm 103$ & $76 \pm 9$ & $<0.0001^{* *}$ \\
\hline Total cholesterol $(\mathrm{mg} / \mathrm{dl})$ & $232 \pm 65$ & $174 \pm 19$ & $<0.0001^{* *}$ \\
\hline Triglycerides $(\mathrm{mg} / \mathrm{dl})$ & $133 \pm 52$ & $98 \pm 20$ & $<0.0001^{* *}$ \\
\hline HDL $(\mathrm{mg} / \mathrm{dl})$ & $46 \pm 11$ & $51 \pm 7$ & $0.02^{*}$ \\
\hline LDL $(\mathrm{mg} / \mathrm{dl})$ & $159 \pm 65$ & $103 \pm 20$ & $<0.0001^{* *}$ \\
\hline
\end{tabular}

*Significant $\mathrm{p}$-value $\leq 0.05$, **highly significant $\mathrm{p}$-value $\leq 0.01$

The receiver operating characteristic (ROC) curve showed that the optimal cutoff value to predict obesity using serum leptin was $23 \mathrm{ng} / \mathrm{ml}$. Although the sensitivity of serum leptin was low (60\%), it was more specific (98.0\%) and had much better positive and negative predictive values $(96.3 \%$ and $71.0 \%$, respectively). The ROC curve for cutoff points of serum leptin for predicting obesity showed that serum leptin more than 23 $\mathrm{ng} / \mathrm{ml}$ was the most accurate diagnostic value for prediction of obesity with an area under curve of (0.87) with significant level of $(p=0.0001)$ (Table 8 , Fig. 1).
Insulin resistance associations: In persons who were homozygous genotype GG, $21.8 \%(n=11)$ had insulin resistance and $78.2 \%(n=35)$ were without insulin resistance. Persons who were heterozygous genotype AG, $62.3 \%(n=19)$ had insulin resistance and $37.7 \%(n=12)$ were without insulin resistance. Persons who were homozygous genotype AA,90\% $(n=$ 10) had insulin resistance and $10 \%(n=1)$ were without insulin resistance. There was a statistical significant difference between resistant and non-resistant persons in all participant $(\mathrm{p}=0.001)$ (Table 9$)$.

Table 5: Distribution of different Leptin gene G2548A genotype per weight status of participants

\begin{tabular}{|c|c|c|c|}
\hline Genotype & Obese $(n=44)$ & Non-obese $(n=44)$ & \multirow{2}{*}{ p-value } \\
\cline { 1 - 3 } GG & $11(25.0 \%)$ & $35(79.5 \%)$ & \multirow{2}{*}{$<0.001^{*}$} \\
\hline AG & $23(52.3 \%)$ & $8(18.2 \%)$ & \\
\hline AA & $10(22.7 \%)$ & $1(2.3 \%)$ & \\
\hline
\end{tabular}

Significant $\mathrm{p}$-value at $<0.05 * *$ highly significant $\mathrm{p}$-value at leptin genotypes in obese vs non obese.GG is wild type, AG is heterozygous genotype and AA is polymorphic type.

\section{Discussion}

In this study, we aimed to investigate the association of Leptin Gene G2548A polymorphism and obesity among obese Egyptians and the relation between leptin resistance and insulin resistance and how both contribute in obesity. Current study results showed that, the mean values of fasting blood glucose and fasting insulin were statistically significantly higher in the obese group in comparison to non-obese group. The incidence of insulin resistance (odds ratio) were statistically significantly higher in obese group than among nonobese group. In agreement, several studies have documented that obesity is associated with an increased risk of developing type 2 diabetes ${ }^{(15)}$. 
Table 6: Allele frequencies for $\mathrm{G} 2548 \mathrm{~A}$ gene in obese and non -obese subjects

\begin{tabular}{|c|c|c|c|c|c|}
\hline Genotype & $\begin{array}{l}\text { Obese } \\
N=44\end{array}$ & $\begin{array}{c}\text { Non- obese } \\
N=44\end{array}$ & P-value & OR $(95 \% \mathrm{Cl})$ & $\begin{array}{c}\mathrm{RR} \\
(95 \% \mathrm{Cl})\end{array}$ \\
\hline GG & $11(25.0 \%)$ & $35(79.5 \%)$ & \multicolumn{3}{|c|}{ Reference } \\
\hline$A G$ & $23(52.3 \%)$ & $8(18.2 \%)$ & $<0.0001 * *$ & $5.6(1.2-13.6)$ & $3.2(1.4-4.8)$ \\
\hline$A A$ & $10(22.7 \%)$ & $1(2.3 \%)$ & $<0.001 * *$ & $23.6(2.7-202.1)$ & $14.2(1.94-103.4)$ \\
\hline$A G+A A$ & $33(75 \%)$ & $9(20.5)$ & $<0.001 * *$ & $7.2(3.1-17.2)$ & $2.9(1.8-4.9)$ \\
\hline \multicolumn{6}{|l|}{ Alleles } \\
\hline G & 45 & 78 & \multicolumn{3}{|c|}{ Reference } \\
\hline A & 43 & 10 & $<0.001^{* *}$ & $5.4(2.6-11.2)$ & $3.4(1.8-5.9)$ \\
\hline Total & $88(100 \%)$ & $88(100 \%)$ & & & \\
\hline
\end{tabular}

Significant $\mathrm{p}$-value at $<0.05 * *$ highly significant $\mathrm{p}$-value at leptin genotypes in obese vs non-obese. $\mathrm{GG}$ is wild type vs $\mathrm{AA}$ polymorphic type. $\mathrm{OR}=$ odds ratio $\mathrm{RR}=$ relative risk, $\mathrm{Cl}=$ confidence interval.

Table 7: Quantifying the association between Leptin Genotype and obesity among studied population

\begin{tabular}{|c|c|c|c|}
\hline Genotype & Odds Ratio & 95\% Confidence Interval & p-value \\
\hline GG & \multicolumn{3}{|c|}{ Reference } \\
\hline AG & 9.15 & $3.20-26.19$ & $<0.001^{*}$ \\
\hline AA & 31.82 & $3.65-277.12$ & $0.002^{*}$ \\
\hline
\end{tabular}

Significant p-value at $<0.05$ **highly significant $p$-value at leptin genotypes in obese vs non obese.GG is wild type vs AA polymorphic type

Obesity promotes both endoplasmic reticulum stresses and a state of chronic low level of inflammation that contributes to insulin resistance ${ }^{(16)}$. This may be explained by the facts that, in obese individuals, adipose tissue releases increased amount of non- esterified fatty acids, glycerol, proinflammatory cytokines and other factors that are involved in the development of insulin resistance ${ }^{(17)}$. In our study, the mean values of serum leptin hormone were statistically significantly higher in obese group in comparison to non-obese group. Because leptin reduces food intake that can affect body weight and body mass index, the co-existence of elevated leptin level with obesity is widely interpreted as leptin resistance. This is concordant with Munzberg et al ${ }^{(18)}$ most obese patients already exhibited elevated circulating levels of leptin because of their increased fat mass. Generally, leptin re- sistance is described as a reduced sensitivity with respect to the anorectic response to exogenously administrated leptin. This study showed that the odds ratio of leptin resistance was statistically significant higher among obese than non-obese group. The mean serum leptin hormone was statistically significant higher among obese group in comparison to non-obese group. In similar study, Mayer et al ${ }^{(17)}$ discussed the coexistence between elevated leptin hormone level and leptin resistance with obesity. They revealed that obesity promotes multiple cellular processes that attenuate leptin signaling, and which amplify the extent of weight gain induced by genetic and environmental factors. In our study, the frequency of allele $G$ was significant higher in non-obese group compared to obese group, while the frequency of allele A was significant higher in obese compared to non-obese. 


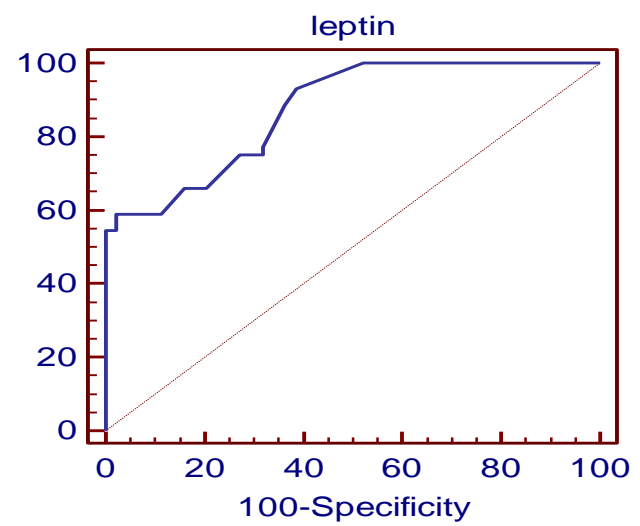

Table 8: Area under the ROC Curve (AUC) of for detecting obesity

\begin{tabular}{|l|c|}
\hline AUC & 0.874 \\
\hline Standard error & 0.0350 \\
\hline $95 \%$ Confidence interval & 0.786 to 0.935 \\
\hline z statistic & 10.679 \\
\hline Significance level of p-value & $<0.0001$ \\
\hline
\end{tabular}

*Significant $\mathrm{p}$-value $\leq 0.05$, **highly significant $\mathrm{p}$-value $\leq 0.01, A \cup C=$ Area under the ROC curve.

Figure 1: ROC Curve (AUC) of for detecting obesity

Table 9: Distribution of Insulin resistance according Leptin genotype in each group

\begin{tabular}{|c|c|c|c|c|}
\hline \multirow{2}{*}{ Study pop. } & \multirow{2}{*}{ Genotype } & \multicolumn{2}{|c|}{ Insulin Resistance } & \multirow{2}{*}{$\mathrm{p}$-value } \\
\hline & & Yes & No & \\
\hline \multirow{3}{*}{$\begin{array}{l}\text { Obese } \\
(n=44)\end{array}$} & GG & $6(55 \%)$ & $5(45 \%)$ & \multirow[t]{3}{*}{$0.220^{\mathrm{a}}$} \\
\hline & AG & $17(79.1 \%)$ & $6(20.9 \%)$ & \\
\hline & $\mathrm{AA}$ & $9(90 \%)$ & $1(10 \%)$ & \\
\hline \multirow{3}{*}{$\begin{array}{c}\text { Non-obese } \\
(n=44)\end{array}$} & GG & $5(11 \%)$ & $30(89 \%)$ & \multirow[t]{3}{*}{$0.131^{\mathrm{a}}$} \\
\hline & $\mathrm{AG}$ & $2(20 \%)$ & $6(80 \%)$ & \\
\hline & AA & $1(100 \%)$ & $0(0 \%)$ & \\
\hline \multirow{3}{*}{$\begin{array}{l}\text { All Participants } \\
\qquad(\mathrm{N}=88)\end{array}$} & GG & $11(21.8 \%)$ & $35(78.2 \%)$ & \multirow[t]{3}{*}{$<0.001^{*}$} \\
\hline & AG & $19(62.3 \%)$ & $12(37.7 \%)$ & \\
\hline & $A A$ & $10(90 \%)$ & $1(10 \%)$ & \\
\hline
\end{tabular}

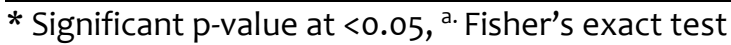

So, obese persons who carry heterozygous genotype AG and homozygous genotype AA of leptin gene G2548A were statistically significantly higher in number compared to non-obese persons. In contrast, non-obese group showed a statistically significantly higher frequency of homozygous genotype GG than obese persons. Previous analyses of the association between the LEP variant and obesity or $\mathrm{BMI}$ have been controversial. The association of the LEP G2548A polymorphism and obesity risk found in our study was also reported in overweight Europeans ${ }^{(19)}$, in a sample of Taiwanese Aborigines' with extreme obesity(20), in Brazilian women ${ }^{(21)}$, and in Finnish men ${ }^{(22)}$. The allele frequency of the G2548A polymorphism observed in this study is in accordance with that of other studies ${ }^{(19,21-23)}$ except for one population from Taiwan, where the $G$ allele frequency was lower than the A allele ${ }^{(20)}$. On the other hand, recent studies have failed to demonstrate an association between this polymorphism and increased BMI or obesity ${ }^{(8,24-26)}$. These different results may arise from interactions of the G2548A polymorphism with environmental factors or other polymorphisms in LEP. Another explanation could be that; The G2548A polymorphism is located at the $5^{\prime}$ end of the promoter region of LEP, and it has been suggested that this remote region may contain inhibitory elements from 
transcription in adipocytes(27). In our study, when comparing AG and GG (reference) genotype the odds ratio was 9.15, which indicates that the carrier of $A G$ genotype has 9 times chance to be obese than GG genotype. When comparing GG and AA genotype the odds ratio was 31.82, which indicates that the carrier of $A A$ genotype has 32 times chance to be obese than GG genotype. Several studies agreed with our study, they revealed that there was a significant association between increase risk of obesity and leptin gene polymorphism ${ }^{(20-22)}$. In our study, Persons who had both leptin and insulin resistance in obese group were, the odds ratio was 15.5 this indicates that persons with both types of resistance were 16 times chance to be obese than persons who haven't either types of resistance. The frequency of heterozygous $A G$ and homozygous $A A$ genotype were statistically significant higher among leptin and insulin resistance group than among non-leptin and noninsulin resistance group. The frequency of A allele was statistically significant higher in leptin and insulin resistance group in comparison to non-leptin and non-insulin resistance group. These results agreed with $(24,28,29)$ which reported that there is positive correlation between variant of the leptin geneG2548A polymorphism and both leptin and insulin resistance. This polymorphism is reported to be associated with metabolic function and adiposity, which contribute to inadequate metabolism of both leptin and insulin hormones that affect the biological function and induce resistance of both hormones. Our study results indicated that there was statistically significant higher incidence of insulin resistance among leptin resistance group than among non-leptin resistance group. These results agreed with Yadav et al(30) which reported that, elevation of leptin and other adipokines and in turn leptin resistance has been associated with insulin resistance, dyslipidemia and atherosclerosis. Data of our study documented that there was a statistical significant positive correlation between both leptin resistance and insulin resistance with age, diabetes mellitus, hypertension, myocardial infarction, positive family history of obesity, elevated BMI, serum cholesterol, serum triglycerides, serum LDL cholesterol and allele frequency of $A$ allele. On the other hand, there were negative correlation between both leptin resistance and insulin resistance with both serum HDL cholesterol and allele frequency of $\mathrm{G}$ allele. These results may be explained by the fact that leptin had peripheral action to stimulate vascular inflammation, oxidative stress, and vascular smooth muscle hypertrophy(31-33). So, leptin resistance may contribute to pathogenesis of obesity, type 2 diabetes, hypertension, dyslipidemia, atherosclerosis and coronary heart disease.

\section{Conclusion}

The study results revealed that most of obese persons in study group had leptin hormone resistance with a significant correlation between leptin resistance and leptin gene $\mathrm{G} 2548 \mathrm{~A}$ polymorphism as all homozygous genotype AA (polymorphic genotype) had leptin resistance. The study also revealed that there was a significant higher incidence of insulin resistance among leptin resistant persons. Current results concluded that leptin gene G2548A polymorphism could be a genetic marker of obesity in Egypt.

Acknowledgements: We wish to thank the participants who provided samples to us.

\section{References}

1. Walley AJ. Blakemore AI. Froguel P. Genetics of obesity and the prediction 
of risk for health. Hum Mol Genet. 2006; 15:124-30.

2. Hossain P, Kawar B, El Nahas M. Obesity and diabetes in the developing world: a growing challenge. $\mathrm{N}$ Engl J Med 2007; 356 (3):213-5.

3. Cummings DE. Schwartz MW. Genetic and pathophysiology of human obesity. Annu Rev Med. 2003; 54:453-71.

4. Mergen $H$, Karaaslan $C$, Mergen $M$, Denïz Özsoy E, Ozata M. LEPR, ADBR3, IRS-1 and 5-HTT genes polymorphisms do not associate with obesity, Endocr J, 2007;54(1): 89-94.

5. Banks WA. The many lives of leptin. Peptides.2004; 25 (3):331-8

6. Friedman JM, Halaas JL. Leptin and the regulation of body weight in mammals. Nature 1998;395 (6704): 763-70.

7. Farooqi IS, Matarese G, Lord GM et al. Beneficial effects of leptin on obesity, $\mathrm{T}$ cell hypo responsiveness, and neuroendocrine/metabolic dysfunction of human congenital leptin deficiency. J. Clin. Invest.2008; 110, 1093-1103.

8. Bjorbak C, Lavery $\mathrm{HJ}$, Bates $\mathrm{SH}$, et al. SOCS3 mediates feedback inhibition of the leptin receptor via Tyr985. J Biol Chem. 2009 ;275 (51): 40649-57.

9. Sivitz WI, Walsh SA, Morgan DA, Thomas MJ, Haynes WG. Effects of leptin on insulin sensitivity in normal rats. Endocrinology. 1997; 138 (8):3395-401

10. de Courten $M$, Zimmet $P$, Hodge $A$, et al. Hyperleptinemia: the missing link in the metabolic syndrome? Diabet Med. 1997; 14 (3):200-8.

11. Tamura Y, Tanaka Y, Sato F, et al. Effects of diet and exercise on muscle and liver intracellular lipid contents and insulin sensitivity in type 2 diabetic patients. J Clin Endocrinol Metab. $2005 ; 90(6): 3191-6$.

12. Reaven $G$. The metabolic syndrome or the insulin resistance syndrome? Different names, different concepts, and different goals. Endocrinol Metab Clin North Am 2004; 33 (2): 283-303.
13. World Health Organization: Obesity 2013 [Accessed on 13th March 2013] http://www.who.int/topics/obesity/en.

14. Matthews DR, Hosker JP, Rudenski AS, et al. Homeostasis model assessment: insulin resistance and beta-cell function from fasting plasma glucose and insulin concentrations in man. Diabetologia 1985; 28 (7):412-9

15. Kassi E, Pervanidou P, Kaltsas G, Chrousos G. Metabolic syndrome: definitions and controversies. BMC Med 2011; 9:48.

16. Margetic S, Gazzola C, Pegg GG, Hill RA. Leptin: a review of its peripheral actions and interactions. Int J Obes Relat Metab Disord. 2000;26 (11): 1407-33.

17. Myers MG, Cowley MA, Münzberg H. "Mechanisms of leptin action and leptin resistance. Annu Rev Physiol. 2010; 70: 537-56.

18. Munzberg $\mathrm{H}$, Bjornholm $\mathrm{M}$, Bates SH, Myers MG., Jr. Leptin receptor action and mechanisms of leptin resistance. Cell Mol Life Sci 2005; 62(6):642-52.

19. Mammès O. Betoulle $D$. Aubert $R$, Herbeth B, Siest G, Fumeron F. Association of the $\mathrm{G}-2548 \mathrm{~A}$ polymorphism in the $5^{\prime}$ region of the LEP gene with overweight. Ann Hum Genet.2000; 64:391-394.

20. Wang TN, Huang MC, Chang WT, et al. G-2548A polymorphism of the leptin gene is correlated with extreme obesity in Taiwanese aborigines. Obesity (silver spring) 2006; 14:183-7

21. Hinuy HM. Hirata MH. Forti $N$, et al. Leptin G-2548A promoter polymorphism is associated with increased plasma leptin and BMI in Brazilian women. Arq Bras Endocrinol Metab. 2008; 52(4):611-6.

22. Huuskonen A. Lappalainen J. Tanskanen $M$, Oksala $N$, Kyröläinen $H$, Atalay M. Genetic variations of leptin and leptin receptor are associated with body composition changes in response to physical training. Cell Biochem Funct. 2010; 28 (4)306-12. 
23. Le Stunff C, Le Bihan C, Schork NJ, Bougnères $P$. A common promoter variant of the leptin gene is associated with changes in the relationship between serum leptin and fat mass in obese girls. Diabetes. 2000; 49 (12):2196-200.

24. Mattevi VS, Zembrzuski VM. Hutz MH. Association analysis of genes involved in the leptin-signaling pathway with obesity in Brazil. Int J Obes Relat Metab Disord. 2002; 26 (9):1179-85.

25. Portolés O. Sorlí JV. Francés F, et al. Effect of genetic variation in the leptin gene promoter and the leptin receptor gene on obesity risk in a population-based case-control study in Spain. Eur J Epidemiol.2006; 21 (8):605-12.

26. Gottlieb MG. Bodanese LC. Leite LE, et al. Association between the Gln223Arg polymorphism of the leptin receptor and metabolic syndrome in free-living community elderly. Metab Syndr Relat Disord.2009; 7:341-8.

27. Gong DW. Bi S. Pratley RE, Weintraub BD. Genomic structure and promoter analysis of the human obese gene. J Biol Chem. 1996; 271 (8):3971-4.
28. Puig KL, Floden AM, Adhikari R, Golovko MY, Combs CK. Amyloid precursor protein and proinflammatory changes are regulated in brain and adipose tissue in a murine model of high fat diet-induced obesity. PLoS One 2012;7(1): e30378..

29. Oral EA, Simha V, Ruiz E, et al. Leptinreplacement therapy for lipodystrophy. N Engl J Med. 2004;346 (8): 5708.

30. Yadav A, Kataria MA, Saini V, Yadav A. Role of leptin and adiponectin in insulin resistance. Clin Chim Acta. 2013; 18; 417:80-4

31. Seufert J. Leptin effects on pancreatic $\beta$-cell gene expression and function. Diabetes 2004;53 (Suppl 1): S152-8

32. Beltoweski J. Leptin and atherosclerosis. Atherosclerosis 2006; 189 (1):4760.

33. Beltoweski J. Role of leptin in blood pressure regulation and arterial hypertension. J Hypertens 2006; 24 (5): 789801. 